\title{
UNITED STATES RESTON, VIRGINIA
}

DEPARTMENT OF THE INTERIOR

GEOLOGICAL SURVEY

WASHINGTON, D.C.

\section{REPORT AND RECOMMENDATIONS}

\section{ON SURFACE WATER RESOURCES}

INVESTIGATION IN TURKEY

This study was undertaken as a part of the cooperative program of the Government of Turkey and the U.S. Geological Survey, under the auspices of the International Cooperation Administration. 


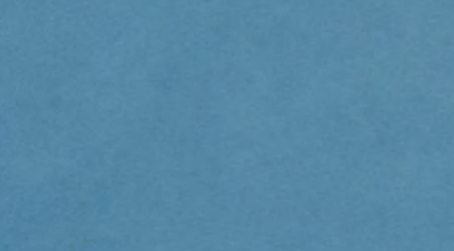

(3)

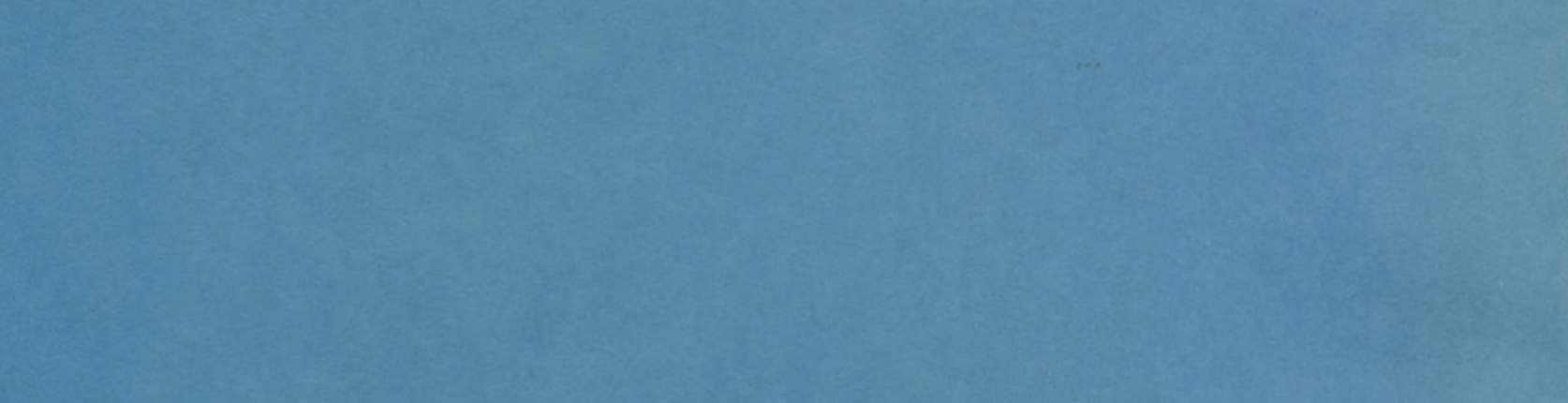
(4.)

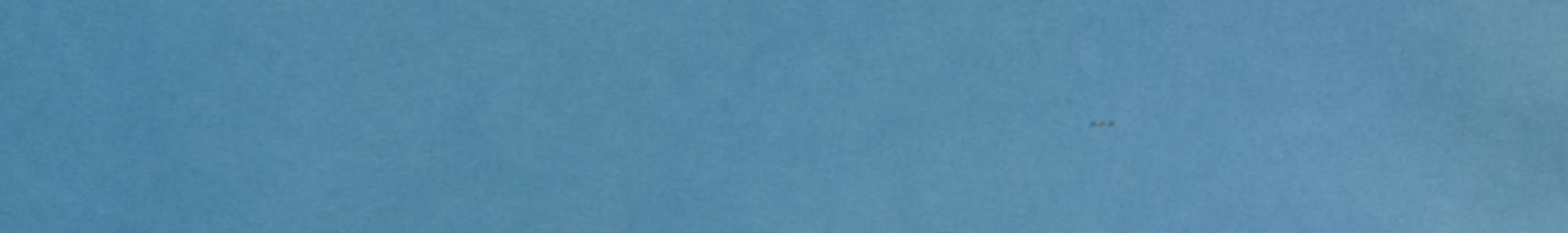

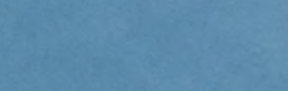

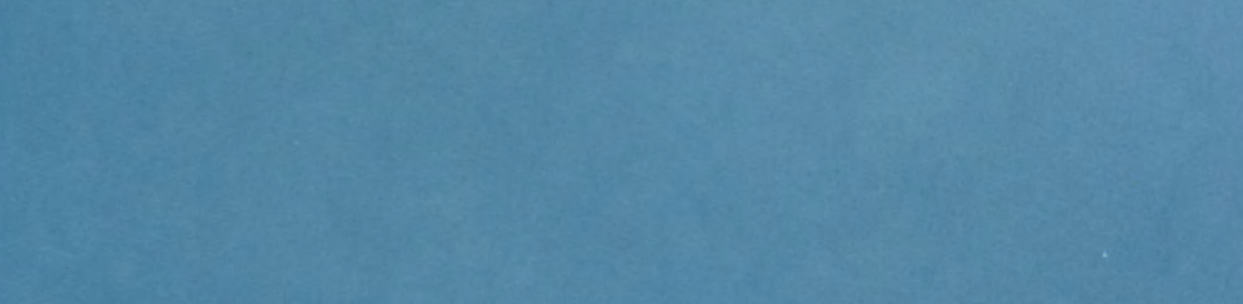

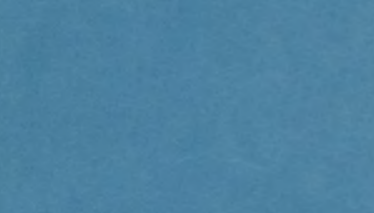

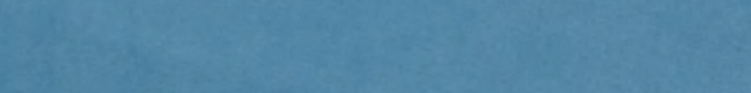
$+3 x^{2}+x^{2}$

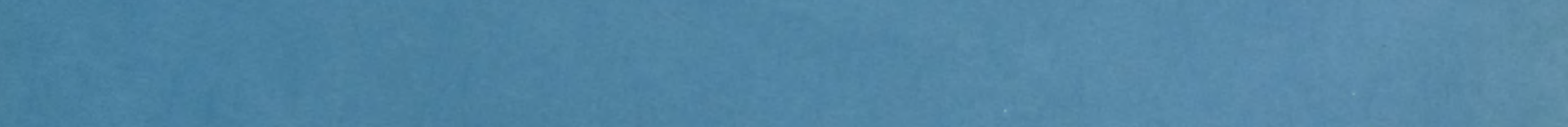

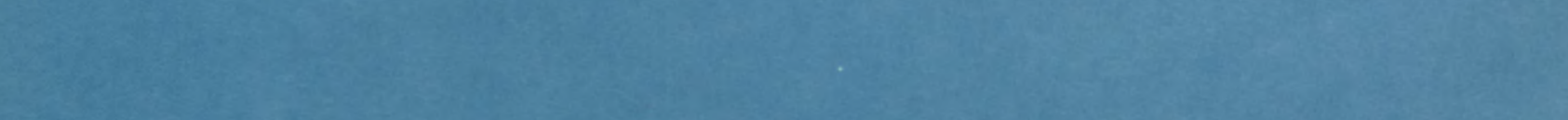

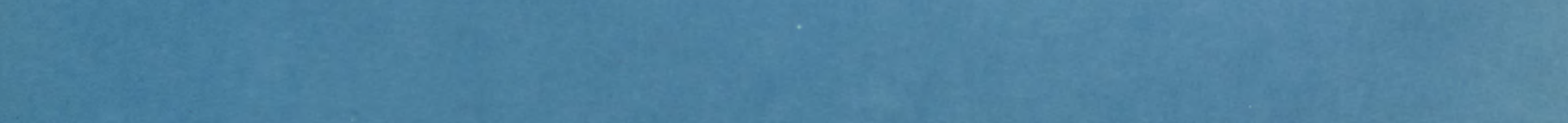

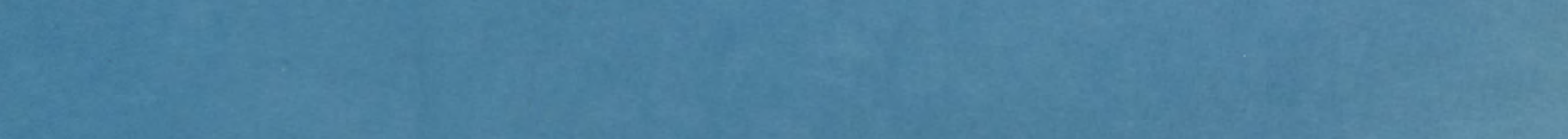

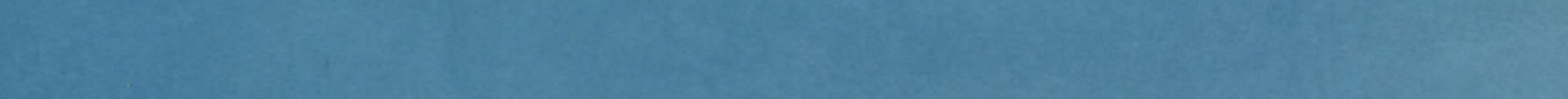

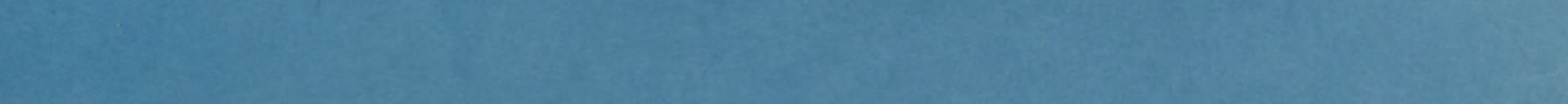
6er

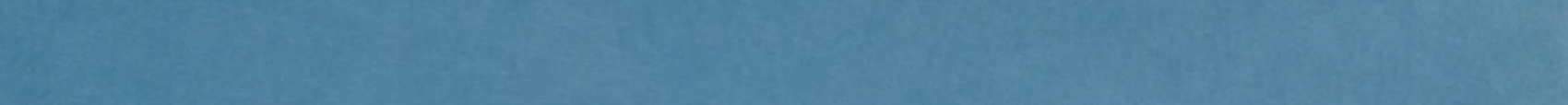

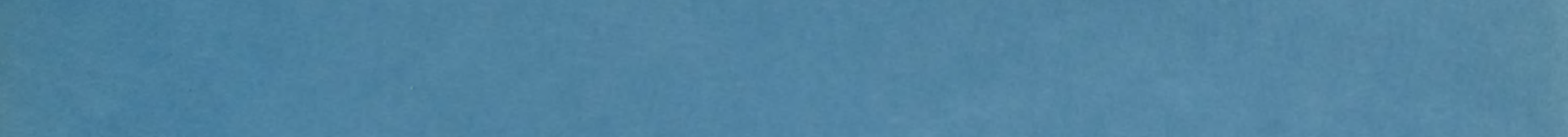

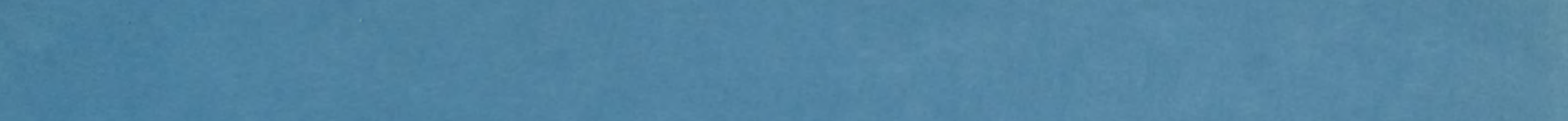

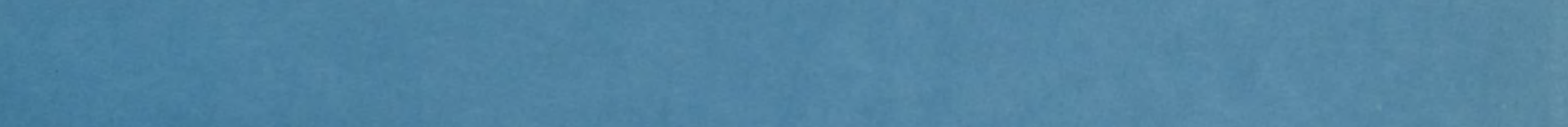
$\sin x=2$.

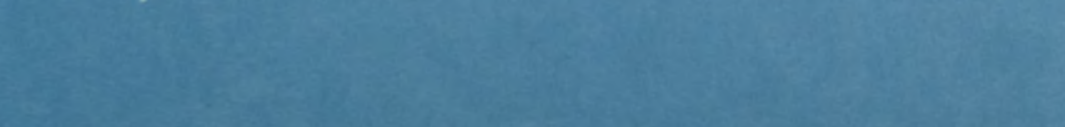




\author{
UNITED STATES \\ DEPARTMENT OF THE INTERIOR \\ GEOLOGICAL SURVEY \\ WASHINGTON, D. C.
}

\title{
US GEOLOGICAL SURVEY \\ LIBRARY
}

FEB 072013

RESTON, VIRGINIA

\section{REPORT AND RECOMMENDATIONS}

ON SURFACE WATER RESOURCES

INVESTIGATION IN TURKEY

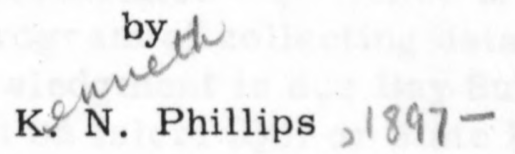





\section{PREFACE}

In 1956 the Government of Turkey, through the International Cooperation Administration (ICA), requested assistance in surface water investigations in Turkey. Pursuant to that request, the ICA and the U. S. Geological Survey (USGS), entered into an agreement, dated March 7, 1957, under which the USGS agreed to provide a consultant to review the current program of streamflow investigations in Turkey and to make recommendations for adjusting or modifying the program to meet the increased needs for information in planning and deve loping the water resources of Turkey. The writer was assigned to this project. He arrived in Ankara, Turkey, on April 1, 1957, after having spent 6 days in Washington, D. C., and several days in travel. He remained in Turkey until July 2, 1957. During that time he spent 18 days in the field inspecting gaging station equipment, field techniques, and the areas where water resources are to be developed, and spent the rest of the period in Ankara in office space provided by the Elektrik Isleri Etut Idaresi (EIE).

The review was facilitated by the helpfulness and cooperation of many Turkish people and Americans in Ankara who have given freely of their time and accumulated experience to help outline, in proper perspective, the program of collecting data on Turkish water resources. Special acknowledgment is due Bay Suleyman Demirel, General Director of Devlet Su Isleri (DSI or State Hydraulics Works Bureau); Dr. Fuat Adali, General Director of Meteoroloji Isleri (MI or Weather Bureau) and his Assistant, Bay Tevfik Aykulu; Bay Huseyin Conturk, Hydrologist for Turkiye Cumhuriyet Karayollari (TCK: Highway Department); and the officials of Elektrik Isleri Etut Idaresi (EIE, Electrical Research Bureau), particularly Bay Ibrahim Deriner, General Director, Bay Hidayet Turanli, Director of Surveys, Bay Hikmet Karg1, Assistant Director of Surveys and Head of Reconnaisance and Development Section, Bay Resit Ogan, Head of Section of Hydrology, and many of the office force and field crews in the Section of Hydrology; Messrs. John H. Berryhill, John Mueller, and Sidney Teweles, ICA Office of Industry; Mr. Philip Dickinson and the engineers and geologists of the River Valley Development Team. All field trips in Turkey were made with engineers of EIE, and office space and facilities in Ankara were provided by EIE. 

Introduction . Page

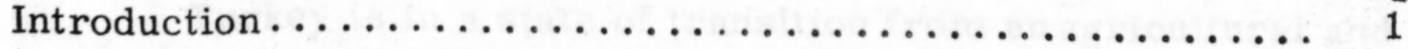

Description of area..................... 1

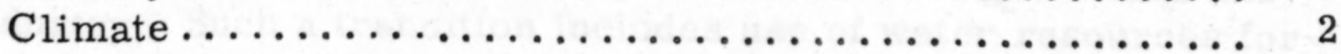

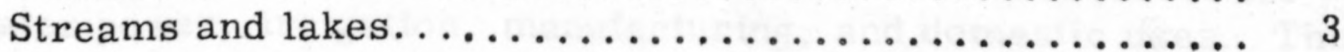

Present use of water ........................... 3

Status of surface water resources investigations ......... 4

History of stream gaging in Turkey............... 4

The existing network of gaging stations ........... 5

Nonrecording stations.................. 5

Recording stations...................... 5

Present field procedures.................... 6

Present office procedures.................... 9

Publication of Records...................... 10

Organizational structure ................... 11

Interagency Coordination. .................. 12

Recommendations........................ 12

Recommendations that do not require aid from

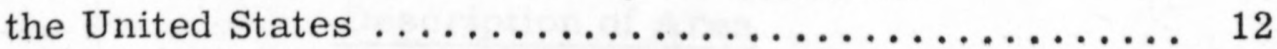

Recommendations that require some aid from

the United States. ...................... 16

Conclusion ............................. 18

\section{ILLUSTRATION}

Figure 1. Stream gaging stations in Turkey, as of

Sept. 30, $1954 \ldots \ldots \ldots \ldots \ldots \ldots \ldots \ldots \ldots \ldots$. 



\section{INTRODUCTION}

Turkey is in a state of transition from an agricultural and pastoral economy to an economy that combines agriculture and industry. Such a transition includes use of water resources for water power, irrigation, manufacturing, and domestic uses. The control of streams for multiple purposes invariably leads to conflicts of interest. Several Turkish streams rise in or flow into other countries. For these reasons, data on the flow of streams over a fairly long period of time are-needed in order to plan the most beneficial use and control of the streams of Turkey.

This report deals largely with the collection of surface water data. The need for data on suspended sediment is considered briefly. In some areas of Turkey ground-water resources are now being studied by a team of Turkish and American geologists and engineers.

\section{Description of Area}

Turkey is commonly divided into two geographic units; (1) Thrace, or Turkey-in-Europe, and (2) Anatolia, or Turkeyin-Asia. These land units are separated by the Bosporus, the Sea of Marmara, and the Dardanelles, navigable waters that connect the Black Sea with the Aegean Sea. Much of the boundary of both land masses is formed by bodies of water at sea level.

Thrace $(23,970 \mathrm{sq} \mathrm{km})$ consists chiefly of a fertile, southward-sloping plain and gently rolling hills, with a range of low mountains running generally from northwest to southeast across the northern part. It is roughly triangular in shape and is bounded by the Black Sea on the northeast and by the Sea of Marmara on the south.

Anatolia $(743,100 \mathrm{sq} \mathrm{km})$ consists largely of a semiarid plateau, with a girdle of mountain ranges near its borders of sufficient height to affect its climate, especially precipitation and runoff. It is roughly rectangular in shape, about $1,500 \mathrm{~km}$ eastwest by $500 \mathrm{~km}$ north-south. 
Konya Basin is a large "closed" basin in south-central Anatolia. In this area the runoff is dissipated by evaporation in saline lakes, the largest being Tuz Golu (Salt Lake) and Beysehir Golu. A somewhat smaller basin near the eastern border of Anatolia drains into Van Golu, which has no surface outlet. Large springs in Manavgat River basin are assumed to have their source in seepage from Konya Basin. Likewise, there are large springs in the basin of Kara So, a tributary of Euphrates River, that are assumed to be due to seepage from Van Golu.

There are large, nearly level plains in many places (near Corum, Diyarbakir, Balikesir, Konya, for example) and narrow, fertile terraces along most of the streams. The large streams have built up extensive deltas where they enter the sea or debouch upon the plains (Yesilirmak, Kizilirmak, Sakarya, Seyhan Rivers, for example).

Forests cover the mountain areas, sparsely in some places and abundantly in others. In the mountainous regions of the central plateau soil erosion is proceeding rapidly, and in some large areas little soil remains.

\section{Climate}

The climate of Turkey is affected by the large, adjacent water bodies (Mediterranean, Aegean, and Black Seas), and by the mountain ranges that girdle Anatolia and cross northern Thrace. The seaward slopes and higher levels of these mountains receive relatively heavy precipitation, as much as 2.5 meter per year near Rize on the Black Sea coast and near Antalya on the Mediterranean coast. Most of the interior plateau of Anatolia, and the province of Thrace, receive from 0.2 to 0.8 meter of precipitation per year falling mostly as thundershowers during the spring months. Temperatures vary with latitude. The southern coast near Antalya has a semi-tropical climate and produces commercial fruits such as oranges, lemons, and bananas. The plateau of Anatolia is higher in the eastern part than in the western. Winters are cold in the higher parts of the plateau. However, rivers are seldom or never frozen over, according to oral reports from several well-informed people, and anchor ice appears to be unknown. In the southeast, near the borders of Syria and Iraq, the summers are extremely hot and the winters mild. The areas along the Sea of Marmara and the Black Sea have moderate temperatures and moderate to heavy precipitation. 


\section{Streams and Lakes}

In Thrace (Turkish Trakya) the largest stream, Meric Nehri, rises in Bulgaria. A large tributary, the Arda, rises in Greece and for a short distance its thalweg is the border between Turkey and Greece. A second large tributary is the Tunca, which rises in Bulgaria and flows through Thrace to join the Meric at Ergene.

In Thrace, the largest fresh-water lake, Terkos Golu, is the principal source of water supply for the city of Istanbul.

The largest streams in Anatolia are the Firat (Euphrates), Dicle (Tigris), Yesilirmak (Green River), Kizilirmak (Red River), Sakarya, Menderes, Manavgat, Seyhan, and Ceyhan. International streams include the Euphrates (flowing into Syria), Tigris (Syria and Iraq), and Coruh and Aras (Russia). The large lakes, Van Golu, Tuz Golu (Salt Lake), and Beysehir Golu, are saline evaporating sumps for basins with no surface drainage to the sea. The larger fresh-water lakes, all in northwestern Anatolia, include Sapanca Golu (used for water supply for the city of Izmit and its paper factory) and the lakes of Iznik, Manyas, and Apolyont.

\section{Present Use of Water}

Irrigation of the fertile plains, river terraces, and deltas has been practiced to some extent for centuries, but irrigation of larger areas requiring Government aid or extensive cooperative effort has begun only recently. The General Directorate of State Hydraulic Works (Devlet Su Isleri, or DSI) has recently completed or is now building a number of dams for irrigation and water power.

A brochure, "Activities of the General Directorate of State Hydraulic Works", Publication No. 25, 1955, states:

"Many irrigation works, both large and small, have been constructed in existing river basins in Turkey generally utilizing surface waters. During recent years it has also been considered to utilize ground water resources for the same purpose and drilling has already been started in Konya, Merzifon, Ceylanpinar, and Balikesir Plains." 
Șurface streams, lakes, or springs are used for municipal supply for the larger cities, and for some industries that require relatively large supplies of water. Progressive industrialization and urbanization of the Nation will inevitably lead to much greater use of water for these purposes, and will require great expansion of prēsent supplies and distribution facilities for some cities. Many of the smaller towns and villages of Turkey have only, springs or wells from which water is carried for domestic use.

All of the streams observed in Anatolia, and Meric River in Thrace, carry large amounts of sediment in suspension. The outflow from the larger reservoirs such as Sakarya and Seyhan is clear.

\section{STATUS OF SURFACE WATER RESOURCES INVESTIGATIONŚ}

\section{History of Stream Gaging in Turkey}

The first five gaging stations in Turkey were established by EIE in 1935; two of these have no published records because of in-. adequate or unstable ratings. Up to 1949 practically all gaging stations established were for the purpose of making studies of electric power possibilities; but beginning in 1950 some stations have been operated to obtain data for other purposes. At the end of water year 1954 there were 244 gaging stations in operation in Turkey, of which only 72 had established curves that permitted publication of daily and monthly flow.

The stations are classified, by primary purpose, as shown. in the following table:

Gaging Stations in Turkey in 1954

$\begin{array}{cccc}\text { Primary Purpose } & \text { Total } & \text { Published } & \text { Percent } \\ \text { Stations } & \text { Records } & \text { Published }\end{array}$

$\begin{array}{lrrr}\text { Electric Energy } & 104 & 37 & 35 \\ \text { Irrigation } & 80 & 26 & 32 \\ \text { Runoff, General } & 62 & 10 & 16 \\ \text { Duplicate Purpose } & -2 & -1 & -\end{array}$


Agencies other than EIE have not published any records of stream flow: any stream gaging they have done has been of a local nature for special project purposes. Unless otherwise stated, procedures and techniques mentioned in this report are those followed by EIE.

Some stream gaging has been done by Devlet Su Isleri (DSI State Hydraulic Works) in connection with the operation of irrigation projects. Etibank (a state agency organized to operate power networks) is now operating three stations above Sariyar Dam on Sakarya Nehri and one below the dam. These stations are equipped with Stevens continuous recorders in 36-inch corrugated pipe wells and shelters, and American-type gaging cables supported by guyed steel I-beams. Price-type (vertical shaft) current meters are used. The operation of these stations began within the last 12 months, and data obtained are to be turned over to EIE for review and publication.

As of April 1957, EIE reports 281 gaging stations in operation: 56 others have been discontinued for one reason or another. In addition, rainfall data are collected by EIE at 22 stations, evaporation data at 20, and temperature data at 12. All such meteorological data are turned over to Devlet Meteoroliji Isleri (MI) for processing and publication.

\section{The Existing Network of Gaging Stations}

The existing stations are distributed with fairly good uniformity over Anatolia. There are no stations in Thrace or near Istanbul, and there are some large areas in Anatolia with only a very few poorly equipped and widely scattered stations. Moreover, many of the stations are not adequately rated and, therefore, discharge records cannot be published. According to EIE, 140 of 281 stations are not now rated (April 1957).

Nonrecording Stations. --Nearly all stations are of the nonrecording type, at which a vertical staff gage of 1 or more 2-meter sections is read once or twice a day by local gage observer. Their readings lack the completeness of a good recorder chart, and quick changes in stage caused by freshets, regulation, or ice effect can not be known.

Recording Stations. --There are (April 1957) 19 stations equipped with recorders that trace a record of stage automatically 
for periods of one week to one month. Of the 4 weekly recorders inspected, one was not operating because of having no chart installed, one had recently been removed to another nearby site because of (inlet ?) trouble, one was tracing a straight line of questionable dependability, and one was making what appeared to be a good trace. Probably the average performance is much better than these few observations suggest. Recorders are generally housed in small hutches over vertical pipes about 10 inches in diameter with a small float, no inside gage, and no provision for flushing silt except the scouring action of the natural surge of the water surface.

\section{Present Field Procedures}

The EIE follows the practice of sending out field parties from Ankara each year to gage streams, each party attending to a small group of one to six stations. There are 16 crews of this sort that can be sent out, usually two or three men to a crew; but there are only 10 cars available of which one or more is usually under repair. These leave Ankara in about February of each year and most of them stay in the field until May or June. At the stations visited they usually obtain from 1 to 50 discharge measurements per season. During this period of intense field activit y, no visits or measurements are made at perhaps three-fourths of the gaging stations in other parts of Turkey; these three-fourths are visited later by roving gaging teams, usually in the low-water season of summer. Discharge measurements are computed and checked in the field. The average number of discharge measurements per station was 4 in 1954 and in 1956.

Current meters used are of the Ott type, each having optional screw-type rotors that may be affixed to an accurately-machined ball-bearing shaft. Meters are generally set at 0.6 depth, or at 0.2 and $0.8 \mathrm{depth}$, and 20 or more ob servations of depth and mean velocity are made in each measurement. During floods on the larger streams, many measurements have been made with the meter propeller barely submerged: mean velocities are then taken from a curve showing true flow for Iower stages plotted against corresponding flows based on 0.2 -depth readings. Depth on floods are commonly computed from cross-section data, allowing for proper gage height. A common rating formula is used for all meters, none of which have been individually rated. Discharge measurements are usually made by one of five methods: 
1. Wading: Small streams that can be waded with hip boots and that do not have velocities higher than about $3.0 \mathrm{~m}$ per.sec.

2. Boats: A large rubber boat is attached with movable sheaves to a semi-permanent cable, about $1.25 \mathrm{~cm}$ in diameter, the boat being moved from station to station by laborers on the shores, who are in some instances responsible for correct positioning of the boat. The meter is attached to a sturdy 2 -meter or 3-meter rod: or in some instances a weight is used to hold the meter, and a reel on the boat is used to ascertain depth. For the greater depth and velocities, it has been the practice to hold the rod and meter over the side of the boat at an angle, with the meter barely submerged and to use a standard cross section to obtain depths. When the velocity is greater than about $3 \frac{1}{2}$ $m$ per sec, or when there is a large amount of surface drift and debris, it is considered unsafe to make gagings from a boat.

3. From Bridges: A lead weight up to 50 kilograms holds the meter in position, and depths are determined from readings of the dial on a sturdy, non-collapsible reel. A galvanized steel strand about $4 \mathrm{~mm}$ in diameter supports the meter and weight; the weight and meter can be raised or lowered by the reel. Soundings have not been corrected for vertical angle, but they may later be adjusted on the basis of a standard cross section. Electrical circuit includes 2 separate insulated bell-cord wires to the meter, one or more batteries, an audible buzzer, and a visible flashing light.

4. From Cable Cars: Five stations are equipped with gaging cars; two of these have been inspected by the writer. The main cables are of $2.5 \mathrm{~cm}$ (approximately) locked-coil strand, not galvanized, supported by vertical steel columns of 2 channels about 6 by $12 \mathrm{~cm}$ laced back-to-back, embedded in concrete and guyed upstream, downstream, and back at $45^{\circ}$ angles in plan. The main cable passes over a saddle to a concrete block, with a heavy turnbuckle in the line. The gaging car is controlled by a 2-drum reel on the shore, with graduated dials that indicate stationing. The car can be lowered to the water surface for gaging during floods, 
either to eliminate air correction or to permit making surface velocity observations with a messenger unit (see no. 5 below). The quality of construction of this physical equipment is excellent; but the cableways seem to be unnecessarily complicated and expensive. Simpler construction in the future would reduce operating costs for personnel as well as initial cost.

5. By Messenger Units: With an endless steel line across the river, e ither on a permanent cableway or a semi-permanent boat cable, surface velocities can be registered by use of a current meter trailing several feet downstream from a small copper boat. For a large stream, the electrical circuit would probably have to be different from that so far observed, perhaps using the single-wire (ground-return) circuit, with the cable across the river insulated from the ground.

In general, sites chosen for making measurement of flow appear to be very good. Current meters observed seem to have had good care. As a check on accuracy of meter registration, a discharge measurement made with a USGS Type AA meter gave 7.48 cubic meters per second; a check measurement at the same cross-section with an EIE Ott meter gave $7.36 \mathrm{~m}$ per sec, or $1.7 \%$ less.

A point-velocity comparison with 7 Ott meters of EIE made on June 29, 1957, on Kizilirmak Nehri below Hirfanli Dam gave the following results:

Meter Point velocity in meters per second

No. $1 \quad$ No. 2 No. $3 \quad$ Average

$\begin{array}{rrrrr}\text { EIE-Ott } 6669 & 0.927 & 0.942 & - & 0.935 \\ 8059 & 0.925 & 0.909 & - & 0.917 \\ 7024 & 0.927 & 0.943 & - & 0.935 \\ 8056 & 0.925 & 0.909 & - & 0.917 \\ 7033 & 0.940 & 0.925 & - & 0.932 \\ 7030 & * 0.813 & * 0.827 & - & - \\ \text { Average of first five above. } & & & 0.927 \\ \text { USGS-AA-W-92774 } & 0.939 & 0.939 & 0.902 & 0.927\end{array}$

* Not used; either error in observation; or meter not in good condition. Further testing of this meter recommended. With the possible exception of meter 7030 , all the above meters appear to give accurate results. 
Some staff gages and recorders apparently have been installed at sites chosen for convenience in installation and observation, with not enough attention being given to the stability of the stage-discharge relation. Many of the stations have a large number of discharge measurements made, usually in the period February to June. Relatively few discharge measurements are made at any stations in December and January. None are known to have been made under conditions of backwater from ice; the possiblility of such backwater has apparently not been considered in computing records of flow; and no obvious discordances of record that could be attributed to ice effect have been observed. However, it seems probable that ice may cause backwater at times in the higher plateau areas--near Erzurum, for example--and any sudden rises in periods of cold weather should be studied for possible backwater effect.

Silt sampling has been barely started. At, 2 gaging stations, EIE collects daily samples by dipping from the surface; the sediment in a 1-liter sample is sent to the laboratory of TCK for filtration and weighing. One depth-integrating sampler has been obtained and is being fitted for use. There is urgent need for data on silt transport on many rivers of Turkey, and for sedimentation surveys in reservoirs.

\section{Present Office Procedures}

Office practices of EIE in the computation of records of discharge have been generally similar to those of the Surface Water Branch, U. S. Geological Survey, but there are a few notable differences:

1. Rating curves are commonly extended on Cartesian coordinates, or area and mean-velocity curves are similarly extended. The writer has urged use of logarithmic paper, and reduction of 0.2 -depth velocities to mean velocities by use of locally applicable coefficients, if 0.8 -depth observations cannot be made.

2. Differences are not shown on rating tables; as a result some tables have slight reversals. (But in general the tables represent smooth curves.) 
3. Lists of discharge measurements do not show shift adjustment required, or percentage departure from applicable rating tables. Some discharge measurements differ by large percentages from published values of discharge.

4. Method of shifting control has not been used to compensate for continual small changes in rating, as shown by results of discharge measurements at some stations.

5. Tables of daily discharge are computed and published to show too many significant figures. When 2 or 3 figures only are dependable, 4, 5, or 6 significant figures have been published.

\section{Publication of Records}

Streamflow data have been published by EIE in 3 publications:

\section{1935-1953 SU YILLARI AKIM NETICELERI.}

(A compilation of daily and monthly discharge records for the period 1935-53 for 73 stations, of which 14 had been discontinued by 1953; approximate flow-duration tables for 3 other stations; location map.)

\section{1954 SU YILI AKIM NETICELERI}

(Daily and monthly discharge for 72 gaging stations; approximate flow-duration tables for 61 other stations for which rating tables are not sufficiently well-defined to ascertain and publish daily discharge; location map and table of stations. Station descriptions include location, drainage areas, datum of gage, period of record, extremes of flow, and rating tables.)

\section{AKIM - ZAMAN GRAFIKLERI}

(Graphs of daily flow at 40 stations, 1935 - 55.)

These publications give the only data generally available on the flow of streams in Turkey. It is expected that a series of annual water-supply papers will be issued, similar in form to no. 2 above. 


\section{Organizational Structure}

Of necessity, water-resources data have been collected by the EIE, an agency that is one of the principal users of such data. In the past a rather large percentage of the total records have been collected and published for use in power studies. Such studies are of great importance, and much of the data so obtained are useful for other purposes. However, there appears to be certain advantages, at least theoretically, in having basic data collected by an impartial agency not directly using the data for planning and design; 'Turkish agencies have been quick to recognize that fact.

Also, there has been some criticism of apparent overlapping of responsibility for obtaining records of streamflow, with operating agencies obtaining data for some planned or constructed projects, and EIE operating a general network of gaging stations.

In the hope of eliminating such overlapping of function, an inter-Ministerial Commission, in April 1954, agreed that MI (Meteoroloji Isleri, or Weather Bureau) should organize and establish stations to furnish all hydrologic observations, as well as meteorologic observations, necessary for the investigation and planning of hydraulic works and their operation. However, nothing was done to implement that agreement. As a result, MI has not taken over the National program of stream gaging, and EIE has continued to do the work within the limits of its funds, personnel, and equipment. Furthermore, MI has recently turned over 5 river-stage stations to EIE for operation.

On May 31, 1957, a group of administrators and engineers of EIE, DSI, and MI considered the matter further and agreed (according to informal advice) to recommend that responsibility for collection of streamflow data should be assigned to a new organization to be created under the new (1957) Ministry for Industry, Power, and Mining.

At present EIE operates all its gaging stations in Turkey from Ankara. This may be the method followed until some of the field staff have sufficient experience to operate suboffices in areas where there are many stations remote from Ankara, and are willing to live in centers near those stations. There would be advantages 
in having such field offices in places like Adana, Diyarbakir, Erzurum, Trabzon, Bursa, and Izmir, to reduce travel costs and to insure frequent, regular measurements in all seasons of the year. However, some overnight or longer field trips still would have to be made from any such offices and from Ankara. It seems likely that other Government offices in these work centers could provide some necessary services for the small suboffices here suggested.

\section{Interagency Coordination}

The EIE, or any successor in stream-gaging work, should keep itself fully informed of the installation and operation by others of any station for measuring river stage or discharge, and should review the data obtained to determine whether the records are good enough and of sufficient public interest to warrant publication of discharge, with credit to the operating agency. Occasional check measurements of flow by EIE should be made to insure reliability of records. Data obtained by the larger cities (Ankara, Istanbul, possibly others) on runoff at their points of diversion should be verified by EIE and published, because of general public interest in municipal water supplies.

\section{RECOMMENDATIONS}

The writer's recommendations may be summarized in two general categories: (1) Recommendations that can be carried out by the Turkish agencies without aid from the United States, and (2) Recommendations that require aid from the United States through its foreign-aid program.

Recommendations that do not require aid from the United States

1. EIE should continue to collect data on streamflow until that function is transferred to another agency by competent Turkish authority, and should strive to increase its funds, personnel, and equipment, in order to function more effectively.

2. If and when some other agency assumes the duty of collecting data on streamflow, the existing staff and equipment of EIE's sections of hydrology should be transferred to the new unit. The new unit should be granted authority for discretionary adminis trative action not less than that now given to EIE. Such agency should be required to publish records of daily and monthly discharge each year. 
3. Publications, whether by EIE or a successor agency, should show, in addition to data now presented, the type of gage, frequency of readings, effect of any upstream storage and diversions, and date, gage height, and results of discharge measurements. Figures of daily discharge should preferably be rounded off, as only 2 or 3 figures are actually significant and within the expected order of accuracy.

4. Other Turkish agencies that may request EIE (or new agency) to install or operate gaging stations should transfer funds adequate to cover the cost up to the time the cost of the work can be included in the EIE budget. In addition, any equipment that is needed should be transferred, or authorization should be given to obtain such equipment, especially equipment calling for foreign exchange.

5. Other Turkish agencies should turn over to EIE all basic data on streamflow they may collect. The EIE should take steps to be informed of any new stations when they are established, including a statement as to purpose of the record and general public interest therein, and should independently make sufficient checks on field data and office computations to determine whether or not the record should be published, with credit to the operating agency.

6. Turkish agencies and American consultants interested in records of streamflow should get together and agree on the criteria, purpose, and general locations of a base or primary network of gaging stations. It is expected that such stations will be measured regularly and operated indefinitely. The records may or may not be directly applicable to a project, but by correlation with short-term records or partial records they could be used to ascertain flow within reasonable limits of accuracy at upstream or downstream sites, or at sites on similar streams in the same hydrologic province. They should cover all geographic areas of Turkey, even areas where there may now be no pressing need for water-resources data, as in Thrace. It is believed that such a basic network should include not less than 150 stations, of which probably 75 would be existing stations, with the remainder to be established as funds become available. The EIE section of hydrology should take the initiative in this matter. 
7. In addition to the network of primary stations, secondary stations and partial-record stations are needed to fill in the gaps between primary stations. Because these stations will be operated generally for five years or less, equipment may be less permanent and cheaper than that for primary stations. In addition, stations will be established from time to time to serve specific project needs.

Some existing stations and s ome yet to be established may well be designated as partial-record stations. For example, at Kizilirmak Nehri at Bafra, the shifting channel makes the mainten ance of a rating impracticable; furthermore, discharge probably could be determined reasonably well by correlation with the upstream station at Sahinkaya. Under the circumstances, it appears that a record of stage at Bafra to record the shape of the flood hydrograph, and a few measurements in periods of steady flow for use in correlation would answer all needs for data. As a second illustration, consider Uluabat Cayi below Apolyont Lake. Here the flow may be reversed at times, when a rapid rise of Susurluk Nehri takes place and storage in Apolyont Lake delays the runoff of Uluabat Cayi. In such a situation, to develop and maintain a rating would require two continuous recorders several kilometers apart on Uluabat Cayi, plus a large number of accurate gagings. Obtaining daily discharge from a single staff gage is not practicable. However, a record of the stage of the lake may be valuable for planning diking or other control measures. A third illustration is Devrez Cayi at Beygircioglu, where large canals divert unknown amounts around the gage, or at times spill large flows back into the river at the gage. Any record obtained here would be meaningless without full data on the diversions. Stations of these types should be either discontinued or recognized as partial-record stations, unless project needs demand data on daily discharge and can support the high cost of such data.

In consultation with other interested agencies, EIE should examine the present list of stations critically and discontinue any stations that do not serve a real purpose or that cannot be rated at a reasonable cost. The objective should be to publish daily and monthly discharge at all regular gaging stations; to publish only gage heights or lists of discharge measurements at special-purpose stations; and to discontinue those stations that do not serve a real purpose or that can be operated properly only at prohibitive cost. 
8. There is a need for peak-flow data on small streams as an aid in rational design of culverts, storm drains, and spillways of small dams. The Highway Department (TCK) is aware of this need, and has taken steps to install a few crest-stage gages above and below culverts. Based on inspection of three such stations, and cursory examination of many other culverts, it is the writer's opinion that most culverts in Turkey have probably been overdesigned. At most of the culverts there is little or no contraction of the stream channel, and the contracted-opening method of computing discharge may not be applicable. It may be better, in general, to determine peak flows by other methods (flow over weirs or through flumes, or by slope-area surveys). Consideration should be given to installing crest-stage gages (at least three per station) on fairly straight reaches where the channel is either uniform or, preferably, gradually contracting downstream, rather than putting crest-stage gages above and below culverts that do not substantially contract the channel. This program should be encouraged and expanded.

9. At present no special effort is made by EIE to ascertain the discharge when an unusual flood occurs at a site where there is no gaging station. Indirect measurements of such floods, especially those causing loss of life or property, or even records of stage at a fixed point referred to a known datum, would be of great interest and value in later years. Field techniques are now being studied, and a serious attempt should be made to apply these techniques whenever an unusual flood occurs at an ungaged site.

10. EIE should (and beyond question will) continue to improve its field and office practices, based on U. S. Geological Survey publications to the extent they are applicable and on the writer's informal oral suggestions. For example, each station should have a discharge measurement made at least every two months; lists of measurements should show the percentage by which each gaging differs from the the rating table in use; shift adjustments should be applied when needed; velocity observations in floods should be made at 0.2 depth rather than just below the surface, if 0.8 depth setting is not possible.

11. Turkish agencies should endeavor to have a currentmeter rating station located possibly at one of Turkey's technical schools, such as the technical university now reported to be under consideration for building at Trabzon or at Erzurum. Until such 
facilities are available, meters should occasionally be checked at some favorable site against a new meter, or against a borrowed meter that has been individually rated and is reserved for making such rating checks.

12. Decentralization of the field work of stream gaging and at least the more elementary office work in preparation of records, is recommended as a long-range objective to be accomplished over a period of several years.

Recommendations that require some aid from the United States

The following recommendations are contingent upon availability of the necessary foreign-aid funds and qualified American personnel. It should be understood that there is a shortage of trained engineers and hydrologists in the Water Resources Division of the Geological Survey, and that the period in which a training program can be performed will depend upon finding a qualified man who is willing to accept an assignment in Turkey and who can be spared from other pressing assignments in the United States. For the purpose of this report, the assumption is made that such an enginner will be available from January 1958 through December 1959, thus spreading the cost over 3 fiscal years.

1. The following training program, consisting of two parts, is recommended for Turkish engineers: (a) Training in Turkey in the collection and processing of water-resources data by an American engineer to be assigned by the Water Resources Division of the Geological Survey, for a period of about two years. At the end of the first year, he should indicate whether in his opinion such training should be extended for an additional period, provided he or a qualified successor can be spared by the Geological Survey, or whether the assistance should be curtailed.

The engineer furnished by the Water Resources Divison should have broad experience in field and office practices of the Surface Water Branch, including indirect computations of discharge (slope-area method, contracted-opening method, Parshall flume, - weirs and dams), and also experience in silt-sampling techniques. Teaching experience would be helpful but may not be essential. Some advance study of the Turkish language would be very helpful. 
(b). Training in America of Turkish personnel. - Within 6 months after beginning his assignment in Turkey, the American hydrologist should report whether or not in his opinion one or more Turkish hydrologists or engineers could profitably be sent to the United States for training in the Water Resources Division, for a period of one year each. Consideration should be given to those Turkish employees who are most likely to remain with the Turkish water resources organization and to become leaders in basic data collection, who are receptive to new ideas, and who have sufficient command of the English language to enable them to learn by reading the literature as well as by receiving direct instruction in field and office practice. Assuming that qualified men will volunteer and that mutually satisfactory arrangements can be made, such training would, in the writer's opinion, be very beneficial to the EIE hydrology section, or to any successor in function.

Consideration should be given to recommending one Turkish engineer for detail to the Quality of Water Branch, for instruction in field and laboratory techniques and office studies related to silt sampling and to sedimentation in reservoirs.

2. Some materials and supplies not readily obtainable in Turkey will be required for improvement of existing facilities and also for training purposes. It is not possible to prepare a detailed list of all such materials and an accurate break-down of costs. It is believed that Turkish authorities will provide labor and locally available materials, and will cooperate in every way to properly install and operate such equipment as can be furnished. The engineer detailed to Turkey should every 3 months request such supplies as are needed, by quarters for the next 12 months.

Materials expected to be needed include: wire-weight gages; cranes and reels for gaging from bridges; portable Canfield-type reels; rubber waders; galvanized wire rope and fittings for cable crossings; gasoline-motor driven pumps to facilitate excavation; gaging cars; water-stage recorders; padlocks, keyed alike; handline sets; headsets; weights in various sizes, 30 to 150 pounds; and current meters. Because of the fact that about 25 Ott current meters and only 1 Price meter are now in use by EIE, it may be desirable to standardize on Ott meters.

A rough estimate of the costs of the above materials and 
supplies, f. o. b. factories mostly in the United States, is as follows:

1958 fiscal year, latter half,

1959 fiscal year,

1960 fiscal year, first half,
$\$ 6,000$

18,000

6,000

To improve the mobility of the field force and thus increase the frequency of gagings, and to provide transportation required by reason of the training and improvement program outlined above, additional transportation is urgently needed. It is recommended that 4-wheel drive pickup trucks with Warn (or similar) front-wheel hubs and 6 heavy-duty tires each be provided at the following rate, for use of EIE hydrology section or any successor in function:

6 in the last 6 months of fiscal year 1958

3 in 1959 year

3 in 1960 year

\section{CONCLUSION}

From 1935 to date several Turkish agencies, especially EIE, have collected data on stream flow in Turkey. Present methods are patterned to a considerable degree on those of the Surface Water Branch of the U. S. Geological Survey. EIE has accepted for operation gaging stations requested by other agencies, sometimes with no transfer of funds to cover the cost of operation, with the result that the work is not adequately financed. While data of great value have been collected, there are still many stations that are not rated and discharge cannot be computed, either because of unfavorable physical conditions at the sites or for lack of funds, manpower, cars, and equipment to do the necessary field work.

Some improvement can be effected by Turkish agencies without American aid; but a grant of assistance in the form of technical assistance in training and of hard-to-get instruments, supplies and materials will greatly increase the collection of data on water resources, with a concurrent improvement in accuracy and dependability of the records. 
The writer gratefully acknowledges the many official and personal favors, chiefly by Turkish and American people employed by EIE and by ICA, and, above all, the prevailing spirit of cordial friendship which added so much to the pleasure of his brief stay in Turkey. 



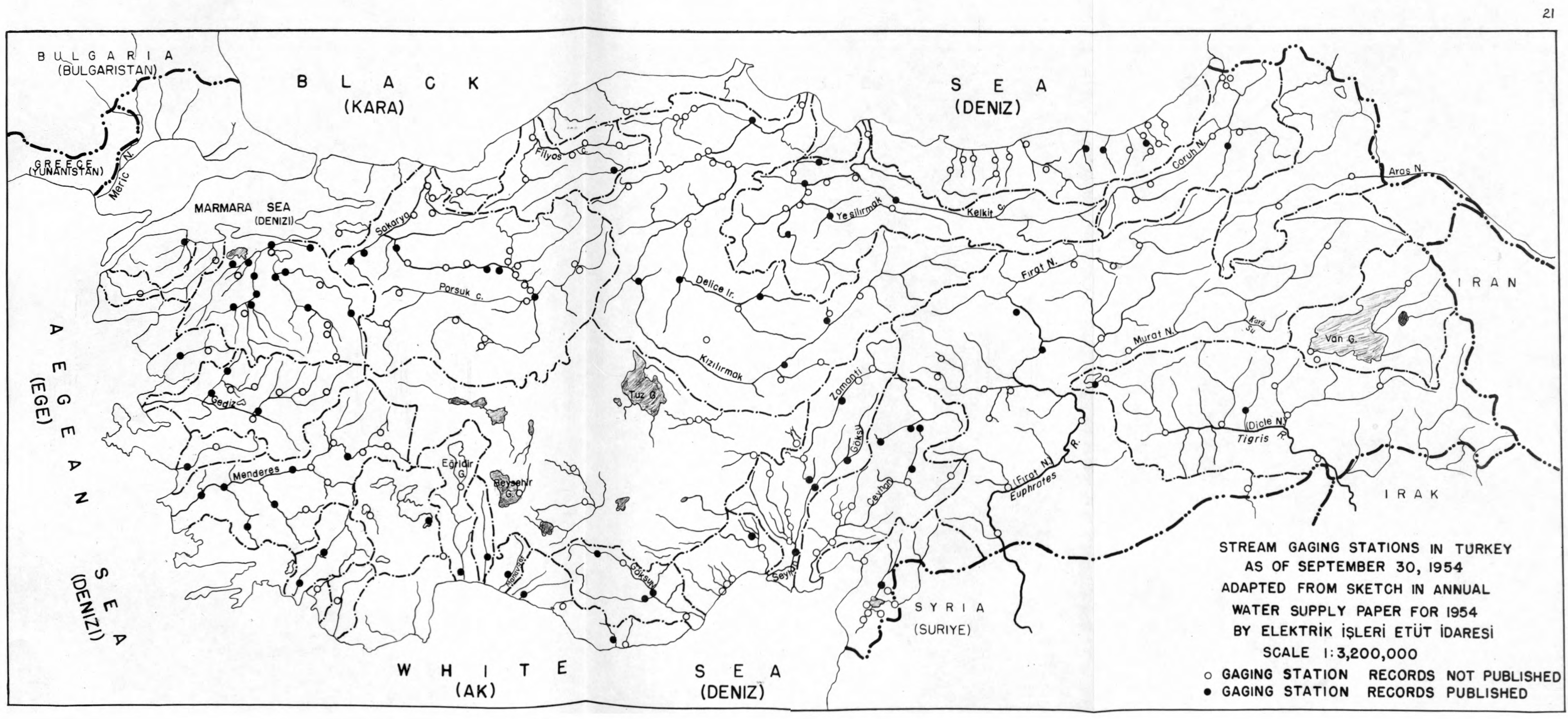




